\title{
A Study of Amir's Psychological Change in The Kite Runner
}

\author{
Chen Kai-fu ${ }^{1}$ \\ ${ }^{1}$ School of Foreign Languages, Leshan Normal University, China \\ Correspondence: Chen Kaifu, School of Foreign Languages, Leshan Normal University, Leshan, Sichuan, China.
}

Received: March 18, 2019 Accepted: April 19, 2019 Online Published: April 21, 2019

doi: 10.5539/elt.v12n5p190 URL: https://doi.org/10.5539/elt.v12n5p190

\begin{abstract}
The Kite Runner is a representative novel by Afghan-American writer Khaled Hosseini. In this novel, Hassan's loyalty moved countless readers while Amir's betrayal shocked and even angered many readers. In the researcher's view, all behaviors of the protagonist, Amir, such as his betrayal, guilt and redemption, are closely related to his psychological changes. From mistrust to doubt, guilt to inferiority, self-accusation to role confusion, and from being willing to love to devotion, different psychological states lead to different emotional needs and behaviors. Admittedly, the whole psychological process is actually a journey of growth for Amir. By employing Erikson's psycho-social development theory to analyze Amir's psychological change in different stages, this paper aims to reveal Amir's inner world so that we can have a better understanding of the reasons for Amir's sin and cowardice.
\end{abstract}

Keywords: The Kite Runner, Amir, psychological change, psycho-social development theory, journey of growth

\section{Introduction}

The Kite Runner was the first novel written by Khaled Hosseini, Afghan-born American writer. In 1999, Hosseini got to know from the news report that the Taliban had banned the activity of kite-flying in Afghanistan. The news reminded him of his childhood in Afghanistan, where he used to play this kind of sport. He thought it was so cruel and unfair for the kids, and this event aroused his interest to write a short story in which two boys loved flying kites. In March, 2001 he began to expand this short story to a novel as suggested by one of his friends. Eventually, this novel was published in 2003, since then it has enjoyed great popularity and has been translated into many versions.

The Kite Runner tells a story between two boys, Amir and his servant, Hassan. In the first half of the novel, Hosseini mainly depicted the friendship between the two boys. The rest half mainly focused on Amir's attempts to amend his guilt by rescuing Hassan's son.

\section{Literature Review}

The Kite Runner has enjoyed much reputation since its publication in 2003 and has attracted many scholars at home and abroad. They studied this novel from different perspectives. Some papers are concerned about multiculturalism. "Building Cultural Competence Through Multicultural Fiction" by Luckhardt thinks that The Kite Runner is an artful example of the power and possibility of multicultural which can be an invaluable tool in the classroom (2010, p. 21). In "To Be Good: The Runner as Allegory of Global Ethics", Jefferess highlights Islamic culturedistinguishes "good Muslim" from "bad Muslim" from the ethical perspective (2009, p. 398). Another focus of studies on this novel is about betrayal and redemption, such as "Images of Salvation and Healing in Shusaku Endo 's Silence and Khaled Hosseini's The Kite Runner" by Elaine Lux and "The Ethics of Painful Reading: Suffering as Means to Redemption, Insight, and Hope in Beloved, Maus, and The Kite Runner" by April Hefner.

At home, Zhang Guangyun and Wang Zhilin explored the images of the kite in The Kite Runner in their paper "On the Images of the Kite in the The Kite Runner". They hold the opinion that "the kite, as an image, is a carrier of multiple metaphor". In her essay "An analysis of the Symbolic Art Techniques in The Kite Runner", Cao Hu thought Khaled Hosseini used symbolic art techniques to reveal many social problems in Afghan. Yu Wengang analyzed the spatial narrative techniques in the narrative process of the novel from the changes of the geography environment, the specific narrative space elements, and the psychological space of the hero Amir in the paper "On the Spatial Narrative Elements in The Kite Runner". And another scholar, Zhang Zhen, in her essay "On the Personality Growth Journey of Amir in The Kite Runner", she used Freud's personality structure theory to 
analyze the contradiction and integration between self-superego and self-self in the process of Amir's growth.

Although there is a lot of research about Amir, they tend to focus on the individual humanity and the personal growth in the spiritual change. They ignore each specific stage of psychological development and the relations between Amir's behaviors and psychological change. So this paper aims to analyze Amir's specific psychological change in different psychological development stages. The author will divide Amir's psychological growth into different stages and analyze them respectively, thus providing more detailed information about the relation between Amir's different behaviors and his psychological condition in self-development process. In addition, it can help the readers have a better understanding about what leads to Amir's different actions in different stages.

\section{Amir's Psychological Changes}

\subsection{From Mistrust to Doubt}

In infant stage and early childhood stage, children need to get enough love and care from their parents to help themselves develop their sense of trust. They need to learn how to view the surrounding environment in a positive way. However, as a kid, Amir did not receive enough care from his father in his infancy and early childhood stage. He lost his mother as soon as he was born. As his mother died, his father hired a nurse to take care of him. In most of time, his father almost just focused his own business, politics and soccer, failing to spend sufficient time accompanying his son. As a result, Amir developed a sense of mistrust to the surroundings.

Children in toddler stage need to get familiar with the environment and learn to connect themselves with this world. However, his father was indifferent to Amir and did not make him feel fatherly love or care, which led Amir even sometimes to blame himself for causing his mother's death. In his opinion, his father's indifference to him is because of his loss of wife, and he was the killer for killing his father's princess. Besides, when Amir confronted with his father's refusal and indifference, he had difficulties trusting his father. When he wanted to sit with his daddy, his daddy would prevent him from getting into the room and say "This is grown-ups' time". Then he would shut the door, leaving Amir alone. Then Amir would sit at the door for one hour or two hour, listening to their talk and laughter.

His father's indifference made him doubt his own identity. He was always afraid that his daddy would be taken away and thought his daddy loved Hassan better than him. So when his daddy wanted to bring Hassan and him to the lake to play, Amir lied to him that Hassan had something to do. All of this was a reflection of his desire for love. He wanted to talk more with his daddy, but at the same time, he usually thought his daddy hated him. This revealed his self-doubt. Amir's father, from his point of view, wanted Amir to become a brave person and be good at soccer. This also made Amir fail to finish his growth to the next development stage. In conclusion, Amir did not accomplish the task of these two stages----developing a sense of trust and autonomy in his infant stage and toddler stage.

\subsection{From Guilt and Inferiority to Jealousy}

According to Erikson's theory, from pre-school age to school age, children are learning to master the surroundings. In this stage, they need to learn to develop initiative and independence with parental encouragement and support. If they find their parents' demands are difficult to meet, they would feel guilty. When Amir was in this stage, he found himself unable to meet his father's requirements to become good at soccer and brave enough to defend himself. He developed a sense of guilt about himself. He found it hard to get his father's attention so that he chose aggressive behaviors, such as throwing pebbles to hit neighborhoods' windows or climbing trees. Each time when he was discovered by Ali, he would say it was Hassan who did it. When he did something wrong, he learned irresponsibility rather than initiative.

In addition, during school stage, children's confidence is of great importance for their future development, and they begin to find their real interests. If they receive parents' recognition and encouragement, they would take efforts to accomplish their tasks and keep persistence. When he was ten years old, Amir became interested in reading and writing. However, when he went to show his father the story he wrote, his father just looked at him and did not offer his time to read it. This made Amir feel being treated with indifference. In this stage, he should have been encouraged to pursue his interest by doing more activities. However, he developed a sense of inferiority because of the lack of support from parents.

Children in this stage can easily be influenced by the attention of their caregivers. In his inner world, Amir was eager for his father's love and care. It is his father's indifference that made him keep inferiority for a long time, which became even stronger when he found his father loved Hassan as if better than him. Wrong psychological feeling led to his jealousy of Hassan. When his father claimed that he would give a harelip surgery as a gift for 
Hassan's birthday, Amir was firstly surprised. He thought it was not worthy to give a servant such a gift, thus he became jealousy. Actually, such kind of feeling was kept for a long time and became stronger as he grew up. For himself, years of longing for love had made him sensitive. Even a little love from his father left him exult or jealousy. He could have been brave to rescue Hassan when Assef raped Hassan, but he did not. In his mind, getting his father back need some sacrifice, so he chose to be coward and indifferent. Such a betrayal was not only because of his cowardice but also because of his jealousy of Hassan. That was also the reason why he slandered Hassan, claiming Hassan had stolen his money and watch. And this behavior led to Hassan's departure.

\subsection{From Self-accusation to Role Confusion}

According to Erikson's theory, children's development of each stage can have huge influence on their next stage. After his betrayal to Hassan, Amir led a life full of self-accusation. He could never forget the scene in which he looked through himself and found his cowardice. He crouched behind the wall, peeking into the alley and later he found himself peeking it for twenty-six years. When a choice is made, from that moment on, people begin to walk on the road of accepting its consequence. No matter how much they regret, they have to take it on their own shoulder. After Hassan's departure, Amir owned all the love of his father. However, he can not get rid of such guilt, being accusing himself whenever he thought about that day and his life with Hassan. When he had to leave Afghan with his father, he thought of Hassan. He hoped Hassan was still there to accompany him. But at the same time, he knew it was impossible.

After they had arrived in the USA, they need to build their new life on their own. So at this time, Amir need to made clear that who he was and what he could do for his family. The USA was totally a new place for him, and his father was no longer like a strong model for him. People in adolescence stage need to connect themselves to the society where they can figure out who they are and build a sense of themselves. However, Amir in this stage faced a role confusion. His life in Afghan was carefree and without any worry about life. But in the USA, they need to make their own living. So when he faced this situation, he did not know what he can do for improving their life.

\subsection{From Being Willing to Love to Devotion}

In early adulthood, people tend to end their role confusion and begin to blend into the society. Once they have established their identities, they can be prepared to love and make commitments. In this stage, Amir gradually became aware of his own identity and became more mature. When his father had conflicts with others, he would make the right choice to maintain their friendly relationship with surroundings. In addition, he eventually became firm that he would major in English writing and become a writer. From this point, it can be seen that he had found his dream and learned how to live with his father in a right way. Besides, in the USA, Amir met Soraya and fell in love with her. Even when he got to know her past, he accept it. And this time, he learned to love and understand others. When his father got a cancer, he gradually understood him and tried to pray for him. He also learned to give his love to surroundings. When there were so many poor people and his father wanted to kill sheep to help them, Amir stopped him and told him to give them money instead of killing livestocks.

The early adulthood stage is generally from twenty to thirty-nine years old. During this stage, Amir went through big changes. He decided to devote himself when he got to know he needed to rescue Hassan's son Sohrab. Here was a contrast of his psychology. Before his adolescence stage, he seemed to live in his own world and just got Hassan's love and loyalty instead of actively devoting himself. When he knew how to love and devote himself, his psychological condition totally changed. He was determined to bring Sohrab back to the USA and to give him a better life. During his fight with Assef, he also showed his willingness to devotion. Coming back to Afghan, he learned to be sympathetic for the hard life of people in Afghan aroused his sympathy.

\section{Conclusion}

A person's development involves different stages, and these stages are closely related one after another. In different stages, the tasks people face are also not fixed. Only when the necessary quality involved in each stage is developed in accordance with our growth, can people complete their growth journey. From Amir's psychological changes, we can see this process at the same time shaped his personal growth road. And our behaviors are closely related to our psychological conditions. When we try our best to understand others' inner world, we can get more knowledge about the reasons of their different choices. Just as Amir, He was just a kid longing for love and attention. When we accuse him of his betrayal, we should also think about the fundamental reasons why he has done so. In this way, not only is it helpful for us to understand Amir's personalities and his behaviors, but also from Amir's personal experience we can get much enlightenment and inspiration that it is significant to attach importance to family education from the psychological perspective. 


\section{References}

Du, J. (2017). A Journey of Self-Actualization of Amir in The Kite Runner.Canadian Center of Science and Education.

Hosseini, K. (2003). The Kite Runner. New York: The Berkley Publishing Group.

Jefferess, D. (2009). To Be Good: The Kite Runner as Allegory of Global Ethics. Journal of Postcolonial Writing, 398-400.

Luclchardt, J. K. (2010). Building Cultural Competence Through Multicultural Fiction. Greenville: East Carolina University.

Lux, E. (2015). Images of Salvation and Healing in Shusaku Endo's Silence and Khaled Hosseini's The Kite Runner. In J. Hallisey, \& M. Weston (Eds.). Making Peace in Our Time. MA: Regis.

Wang, Q. (2017). Identity and Initiation---Analysis of Relationship Between Father and Son in The Kite Runner. University of Electronic Science and Technology of China.

Yu, T. (2013). An Analysis of The Kite Runner from the Perspective of Initiation story. Shengyang: Liaoning University.

Yu, W. G. (2018). Brief Analysis of Spatial Narrative Elements in the Kite Runner. Journal of Huaihai Institute of Techonology (Humanities \& Social Science Edition), 46-48.

Zhang, G. Y., \& Wang, Z. L. (2014). On the Images of the Kite in the The Kite Runner. Overseas English, 230-231.

Zhang, Z. (2017). An Analyis of Personality Development of Amir in The Kite Runner. Journal of Shananxi Xueqian Normal University, 122-124.

\section{Copyrights}

Copyright for this article is retained by the author(s), with first publication rights granted to the journal.

This is an open-access article distributed under the terms and conditions of the Creative Commons Attribution license (http://creativecommons.org/licenses/by/4.0/). 